\title{
ANALISIS KEHILANGAN KARBON ORGANIK TANAH PADA ADAERAH ALIRAN SUNGAI DELI (DAS) DELI PROVINSI SUMATERA UTARA
}

\author{
Yulia Fitri Harahap \\ Jurusan Pendidikan Geografi, Fakultas IImu Sosial \\ Universitas Negeri Medan, Indonesia \\ Email: yuliafitriharahap@gmail.com
}

\begin{abstract}
This study aims to (1) Analyze the relationship between surface runoff and soil organic carbon loss in the Deli River Basin. (2) Determine the amount of soil organic carbon loss in the Deli DAS for a year. Observation and measurement techniques conducted this research at the sample point, namely at the Deli Watershed outlet, namely by taking water samples per water level and documentation techniques to collect secondary data related to the study area. Data analysis techniques used include qualitative data analysis techniques and qualitative analysis which provides for analysis of laboratory data for water sample testing to see organic carbon content per water level, statistical data analysis to analyze the influence and relationship of surface flow with water level in the Flow Area Deli River and calculate the total soil organic carbon loss in the Deli River Basin, and descriptive data analysis to describe soil organic carbon loss in the Deli River Basin. The results showed (1) there was an influence between surface runoff and soil organic carbon loss with a positive linear relationship where an increase would follow any increase in surface runoff in soil organic carbon loss, (2) soil organic carbon loss in the Deli River Basin was 6.04 tons/ha/ year.
\end{abstract}

Keywords: watershed, Soil Organic Carbon, High Water Level

\begin{abstract}
Abstrak
Penelitian ini bertujuan untuk (1) Menganalisis hubungan aliran permukaan dengan kehilangan karbon organik tanah di DAS Deli. (2) Mengetahui jumlah kehilangan karbon organik tanah di DAS Deli selama setahun. Penelitian ini dilakukan dengan teknik observasi dan pengukuran pada titik sampel yaitu di outlet Daerah Aliran Sungai Deli yaitu dengan mengambil sampel air per tinggi muka air dan teknik dokumentasi untuk mengumpulkan data sekunder yang berkaitan dengan daerah penelitian. Teknik analisis data yang digunakan antara lain teknik analisis data kualitatif dan analisis kuantitatif yang meliputi analisis data laboratorium untuk uji sampel air untuk melihat kadar karbon organik per tinggi muka air, analisis data statistik untuk menganalisis pengaruh dan hubungan aliran permukaan dengan tinggi muka air di Daerah Aliran Sungai Deli serta menghitung total kehilangan karbon organik tanah di Daerah Aliran Sungai Deli, dan analisis data deskriptif untuk mendeskripsikan kehilangan karbon organik tanah di Daerah Aliran Sungai Deli. Hasil penelitian menunjukkan (1) terdapat pengaruh antara aliran permukaan dengan kehilangan karbon organik tanah dengan hubungan linier positif dimana setiap terjadinya peningkatan aliran permukaan akan diikuti dengan peningkatan kehilangan karbon organik tanah, (2) kehilangan karbon organik tanah di Daerah Aliran Sungai Deli adalah sebesar 6,04 ton/ha/tahun.
\end{abstract}

Kata Kunci: DAS, Karbon Organik Tanah, Tinggi Muka Air 


\section{PENDAHULUAN}

Daerah Aliran Sungai (DAS) merupakan daerah yang dibatasi oleh topografi pemisah air yang terkeringkan oleh sungai atau sistem saling berhubungan sedemikian rupa sehingga semua aliran sungai yang jatuh di dalam akan keluar dari saluran lepas tunggal dari wilayah tersebut. Sebagai suatu sistem, dalam DAS terdapat masukan, proses, dan keluaran. Masukan berupa hujan, radiasi, teknologi, sumberdaya manusia. Proses yang terjadi berupa proses fisika, biologi, kimia yang meliputi penguapan, infiltrasi, erosi, longsor, pelapukan, pengangkutan dan pengendapan sedimen, aliran energi, serta dinamika penduduk. Keluaran berupa hasil air, hasil sedimen, unsur hara dan kimia yang terangkut oleh aliran sungai, dan hasil dalam pengelolaan lahan oleh manusia (Haeruman, 1994 dalam Ashari, 2012).

Salah satu proses yang terjadi di dalam Daerah Aliran Sungai adalah proses siklus karbon. Siklus karbon tersebut salah satunya dipengaruhi oleh adanya erosi. Erosi merupakan pengikisan material tanah oleh media tertentu seperti air, angin, dan sebagainya yang mengakibatkan berpindahnya unsur hara, nutrien dan zat-zat organik dalam tanah ke tempat lain. Ketika terjadi erosi permukaan, tanah akan kehilangan beberapa unsur yang terdapat di dalamnya termasuk karbon organik tanah. Karbon organik tanah yang telah tererosi akan masuk kedalam saluran sungai dan mengalir sebagai material sedimen melayang (Suspended Load) menuju lautan melalui outlet DAS. Peristiwa tersebut merupakan salah satu bagian dari siklus karbon global yang sangat penting untuk dikaji demi keseimbangan lingkungan.

Karbon organik tanah (KOT) memainkan peranan penting dalam siklus karbon global, karena karbon organik tanah merupakan pole karbon permukaan bumi yang paling besar. Tanah merupakan salah satu unsur terpenting dalam penyimpan karbon dalam skala global. Tanah dapat berfungsi sebagai sumber (source) $\left(\mathrm{CO}_{2}, \mathrm{CH}_{4}\right.$ dan $\left.\mathrm{N}_{2} \mathrm{O}\right)$ atau kuburan (sink) $\left(\mathrm{CO}_{2}\right.$ dan $\left.\mathrm{CH}_{4}\right)$ dan berbagai gas rumah kaca, tergantung pada penggunaan lahan dan pengelolaannya (Lal, 2002 dalam Widiyatmaka,dkk 2012). Kehilangan karbon organik tanah tidak terlepas dari proses erosi yang disebabkan oleh tingginya curah hujan. Curah hujan yang tinggi menyebabkan munculnya aliran permukaan yang menyebabkan erosi. Aliran permukaan tersebut membawa material erosi ke saluran sungai sebagai suspended load. Aliran permukaan yang terjadi dapat menambah tinggi muka air serta debit aliran pada sungai.

Kehilangan karbon organik tanah dapat terjadi di Daerah Aliran Sungai yang mengalami degradasi. Daerah Aliran Sungai (DAS) Deli merupakan salah satu DAS yang melintasi kota Medan dari hulu hingga hilir. Daerah Aliran Sungai (DAS) Deli adalah sumber air utama untuk penghidupan masyarakat di Kota Medan. Namun, dalam beberapa tahun terakhir, debit air pada DAS Deli telah mengalami penurunan yang diakibatkan oleh perubahan penggunaan lahan yang mengakibatkan tingginya tingkat erosi yang terjadi. Tercatat DAS Deli mengalami erosi mencapai rata-rata 179,6 ton/ha/tahun. Berdasarkan hasil penelitian Hutapea, 2012, Sub DAS Petani menyumbang erosi terbesar yaitu dengan rata-rata erosi 60,9 ton/ha/tahun disusul Sub DAS Babura dengan rata-rata erosi 36,4 ton/ha/tahun, Sub DAS Bekala dengan rata-rata erosi 38,7 ton/ha/tahun, Sub DAS Simai-mai dengan rata-rata erosi 41,1 ton/ha/tahun, Sub DAS Paluh Besar dengan rata-rata erosi 1,8 ton/ha/tahun, Sub DAS Sei Kambing dengan rata-rata erosi 0,5 ton/ha/tahun dan Sub DAS Deli dengan rata-rata erosi 0,2 ton/ha/tahun. Kondisi tersebut mengakibatkan tingginya kehilangan karbon organik tanah yang dapat mengganggu siklus karbon global serta menurunkan kualitas tanah sebagai salah satu media tumbuh tanaman dan pendukung sistem kehidupan makhluk hidup lainnya.

Tingginya tingkat erosi di DAS Deli tidak terlepas dari peranan hujan sebagai salah satu faktor terbesar yang menyebabkan terjadinya erosi. Menurut Hudson, 1979 (dalam Banuwa 2013), kemampuan hujan di daerah tropis dalam menimbulkan erosi lebih besar daripada daerah beriklim sedang. Hal ini disebabkan, karena curah hujan di daerah tropis relatif mempunyai intensitas, lama dan jumlah kejadian hujan yang lebih besar daripada di daerah beriklim sedang. DAS Deli merupakan salah satu DAS yang terletak di daerah beriklim tropis dengan curah hujan harian maksimum mencapai $155 \mathrm{~mm}$. Hal 
tersebut tentu menjadi salah satu faktor yang sangat berpengaruh terhadap kehilangan karbon organik tanah, ditambah dengan perubahan penggunaan lahan yang telah terjadi dalam beberapa tahun terakhir di DAS Deli. Kehilangan karbon organik tanah perlu diteliti untuk mengetahui dan menetapkan langkah yang tepat dalam pelestarian lingkungan baik dalam skala lokal maupun skala global.

Tujuan penelitian ini adalah untuk menganalisis hubungan antara aliran permukaan dengan kehilangan karbon organik tanah pada DAS Deli dan mengetahui jumlah kehilangan karbon organik tanah pada DAS Deli selama setahun.

\section{METODE PENELITIAN}

Penelitian dilakukan di DAS Deli, Provinsi Sumatera Utara. Pemilihan lokasi ini didasarkan kepada:

- Sungai Deli merupakan salah satu yang melalui kota Medan dan menjadi salah satu sungai yang berkaitan langsung dengan sistem kehidupan masyarakat di Kota Medan

- DAS Deli telah mengalami degradasi lahan dan perubahan penggunaan lahan selama beberapa tahun terakhir sehingga berpotensi terjadinya kehilangan karbon organik tanah yang sangat besar

- Berdasarkan penelitian sebelumnya, Tingkat Bahaya Erosi pada DAS Deli termasuk kedalam kategori erosi berat dengan 407,21 ton/ha/tahun (Rahmad, 2017). Sejalan dengan tingginya laju erosi, peneliti tertarik untuk meneliti karbon organik yang hilang oleh erosi tersebut.

Populasi dalam penelitian ini adalah seluruh material erosi yang terangkut oleh aliran permukaan di DAS Deli, Sumatera Utara. Adapun sampel dalam penelitian ini adalah sampel air yang diambil pada outlet sungai Deli pada variasi ketinggian muka air yaitu 3 sampel diambil pada saat setelah terjadi hujan dan 3 sampel diambil pada saat tidak terjadi hujan. Teknik yang digunakan dalam mengambil sampel air adalah teknik purposif sampel pada setiap ketinggian muka air. Pengambilan sampel air menggunakan teknik point integrating sample atau integrasi titik. Teknik pengumpulan data pada penelitian ini dilakukan dengan teknik yaitu teknik observasi dan dokumentasi. Observasi dan pengukuran dilakukan pada titik sampel yaitu di outlet DAS yaitu dengan mengambil sampel air per tinggi muka air yang kemudian masing-masing sampel akan diuji kadar karbon organik tanahnya. Teknik dokumentasi dilakukan untuk mengumpulkan data sekunder yang berkaitan dengan daerah penelitian seperti curah hujan, jenis tanah, batas administrasi, kemiringan lereng, penggunaan lahan, data tinggi muka air dan data debit air tahunan.

Teknik analisis data yang digunakan antara lain teknik analisis data kualitatif dan analisis kuantitatif yang meliputi analisis data laboratorium, analisis statistik dan analisis deskriptif. Uji laboratorium dilakukan untuk mendapatkan konsentrasi karbon organik dalam muatan sedimen pada setiap tinggi muka air. Metode/alat yang digunakan untuk menganalisis sampel adalah spektrofotometri yang dilakukan di Laboratorium Balai Teknik Kesehatan Lingkungan dan Pengendalian Penyakit (BKLPP). Kelas I Medan. Analisis data statistik meliputi Analisis korelasi pearson digunakan untuk menganalisis hubungan aliran permukaan dengan kehilangan karbon organik tanah. Pengaruh aliran permukaan terhadap kehilangan karbon organik tanah dapat diketahui dengan analisis statistik regresi linier dengan menjadikan tinggi muka air sebagai variabel bebas (X) dan konsentrasi karbon organik sebagai variabel terikat $(Y)$. Hasil analisis regresi akan menghasilkan persamaan dan nilai korelasi. Persamaan yang dihasilkan oleh analisis regresi digunakan untuk menghitung kehilangan karbon organik tahunan di DAS Deli yaitu dengan mensubstitusi nilai tinggi muka air bulanan DAS Deli yang didapat dari BWS II Wampu Sei Ular terhadap nilai $X$.

Kehilangan karbon organik tahunan didapatkan dari penjumlahan rerata kehilangan karbon organik bulanan. Rerata kehilangan karbon organik bulanan tersebut kemudian dibuat menjadi sebuah kurva kehilangan karbon organik bulanan. Jumlah total kehilangan karbon organik tanah selama setahun diperoleh dengan penjumlahan konsentrasi karbon organik setiap bulan. Penjumlahan kehilangan karbon organik setiap bulan selama setahun, didapatkan dengan menghitung luas daerah yang berada 
di bawah kurva kehilangan karbon bulanan tersebut. Luas dibawah kurva kehilangan karbon organik dihitung dengan menggunakan metode konsep Integral Reimenn. Sebagian luas kurva dihitung dengan menggunakan integral tentu dengan rumus:

$$
\int_{a}^{b} F(x) d(x)
$$

dan bagian luas kurva dihitung dengan menggunakan rumus luas segitiga dan persegi panjang yaitu:

Luas persegi panjang = panjang $\times$ lebar Luas segitiga $\quad=\frac{\text { alas } x \text { ting } i}{2}$

Setelah luas kurva kehilangan karbon organik tanah didapatkan, selanjutnya maka akan didapatkan kehilangan karbon organik tanah tahunan DAS Deli dalam satuan $\mathrm{mg} / \mathrm{l}$ yang kemudian diubah ke dalam ton/ha/tahun yaitu dengan mengalikan hasil luas kurva dengan total debit air DAS Deli (liter) yang akan dikonversikan ke satuan ton kemudian dibagikan dengan luas DAS Deli ( $\mathrm{Ha})$.

\section{HASIL DAN PEMBAHASAN}

\section{Hubungan Aliran Permukaan dengan Kehilangan Karbon Organik Tanah di DAS Deli Provinsi Sumatera Utara}

Kehilangan karbon organik tanah dapat terjadi oleh aliran permukaan yang ditimbulkan oleh energi kinetik air hujan yang menyebabkan butiran-butiran dalam tanah terhempas ke tempat lain. Butiran-butiran tanah tersebut kemudian akan dibawa oleh air ke saluran sungai sebagai suspended load. Analisis statistik korelasi pearson dilakukan untuk melihat ada tidaknya hubungan yang signifikan antara aliran permukaan dengan kehilangan karbon organik tanah di DAS Deli dengan menggunakan Software SPSS 20. Setelah melihat hubungan antara aliran permukaan dengan kehilangan karbon organik tanah di DAS Deli kemudian dibuat Carbon Organic Rating Curve dengan membandingkan 2 variabel yaitu tinggi muka air $(\mathrm{cm})$ dengan konsentrasi karbon organik (mg)/l. Variabel tinggi muka air mengindikasikan tingkat tinggi rendahnya aliran permukaan yang terjadi pada DAS sedangkan konsentrasi karbon organik menunjukkan besaran karbon organik yang terkonsentrasi dalam muatan suspensi yang dibawa oleh aliran sungai yang merupakan hasil dari erosi permukaan.

Carbon Organic Rating Curve disusun dengan menggunakan analisis statistik regresi linier. Variabel yang digunakan yaitu tinggi muka air yang didapat dari pengukuran lapangan di titik lokasi pengambilan sampel yaitu hilir Sungai Deli dan konsentrasi karbon organik yang didapat dari hasil analisis uji laboratorium. sampel air berdasarkan tinggi muka air. Hasil pengukuran tinggi muka air dan konsentrasi karbon organik dapat dilihat pada Tabel 1 sebagai berikut:

Tabel 1. Hasil Pengukuran Tinggi Muka Air dan Konsentrasi Karbon Organik pada Daerah Aliran

\begin{tabular}{cccc}
\multicolumn{3}{c}{ Sungai (Deli) } \\
\hline No & Kondisi & Tinggi Muka Air (cm) & $\begin{array}{c}\text { Karbon } \\
\text { Organik } \\
(\mathbf{m g} / \mathbf{l})\end{array}$ \\
\hline 1 & Tidak Terjadi Hujan & 278 & 19 \\
2 & Tidak Terjadi Hujan & 262 & 17 \\
3 & Tidak Terjadi Hujan & 292 & 19 \\
4 & Sesaat Setalah Hujan & 330 & 40 \\
5 & Sesaat Setelah Hujan & 322 & 34 \\
6 & Sesaat Setelah Hujan & 306 & 20 \\
\hline
\end{tabular}

Sumber: Hasil Pengukuran Lapangan dan Analisis Laboratorium, 2018

Tabel 1. menunjukkan konsentrasi karbon organik pada masing-masing tinggi muka air. Tinggi muka air rata-rata pada saat tidak terjadi hujan adalah $277,3 \mathrm{~cm}$ sedangkan pada saat setelah terjadi hujan adalah 319,3 $\mathrm{cm}$. Dapat dilihat pada Tabel 1. bahwa tinggi muka air bervariasi, hal ini dikarenakan waktu pengambilan sampel air yang sengaja dilakukan dalam 2 kondisi yaitu sesaat setelah hujan dan ketika tidak terjadi hujan. Berdasarkan Tabel 1. dapat dilihat bahwa semakin tinggi nilai tinggi muka air maka akan 
diikuti dengan peningkatan konsentrasi karbon organik, hal tersebut dapat dilihat dari nilai tinggi muka air yang paling besar yaitu sebesar $330 \mathrm{~cm}$ terdapat nilai konsentrasi karbon organik yang paling besar juga yaitu sebesar $40 \mathrm{mg} / \mathrm{l}$, begitu juga sebaliknya nilai tinggi muka air terendah yaitu $262 \mathrm{~cm}$ mengandung konsentrasi karbon organik yang paling rendah juga yaitu $17 \mathrm{mg} / \mathrm{l}$.

Berdasarkan hasil analisis SPSS 20 diperoleh koefisien korelasi pearson adalah sebesar 0,023 dengan nilai signifikasi $0,023<0,05$. Hasil tersebut menunjukkan terdapat hubungan yang signifikan antara tinggi muka air dengan konsentrasi karbon organik, hal itu berarti bahwa terdapat hubungan yang cukup signifikan antara terjadinya aliran permukaan dengan kehilangan karbon organik tanah.

Pengaruh tinggi muka air yang mengindikasikan aliran permukaan terhadap konsentrasi karbon organik tanah dapat dilihat dari hasil analisis statistik regresi linier dengan menjadikan tinggi muka air sebagai variabel $X$ dan debit karbon organik karbon organik sebagai variabel $\mathrm{Y}$. Berdasarkan hasil analisis statistik regresi linier dengan menggunakan SPSS, maka didapatkan hasil analisis pada tabel 2 .

Tabel 2. Hasil Analisis Regresi Antara Debit Karbon Organik(Y) dengan Tinggi Muka Air(X)

\begin{tabular}{lr} 
Persamaan hasil regresi & $Y=-71,848+0,324 x$ \\
$r^{2}$ & 0,764 \\
$t_{\text {thitung }}$ & 3,597 \\
Nilai sigifikasi & 0,023 \\
Nilai Probabilitas & 0,05 \\
\hline
\end{tabular}

Sumber: Hasil Analisis, 2018

Uji probabilitas dan uji nilai t kemudian dilakukan untuk melihat ada atau tidaknya pengaruh variabel $X$ (tinggi muka air) terhadap variabel $Y$ (konsentrasi karbon organik), sebagai berikut:

- Uji Probabilitas: berdasarkan hasil analisis, nilai signifikasi yang didapat adalah sebesar 0,023 . Nilai tersebut lebih kecil dari nilai probabilitas $0,05(0,023<0,05)$ hal tersebut menunjukkan bahwa variabel Tinggi muka air $(X)$ berpengaruh terhadap variabel $\mathrm{Y}$ (konsentrasi karbon organik).
- Uji nilai t: nilai thitung yang didapat dari hasil analisis adalah 3,597, nilai tersebut lebih besar dari nilai $t_{\text {tabel }}$ sebesar 3,18245 (lampiran 3) atau thitung 3,597> $t_{\text {tabel }}$ 3,18247 . Hal tersebut juga memperkuat adanya determinasi atau pengaruh variabel $X$ terhadap variabel $Y$.

Berdasarkan hasil analisis tabel 2. maka didapatkan hasil Carbon Organic Rating Curve yang dimuat pada gambar 1 . 


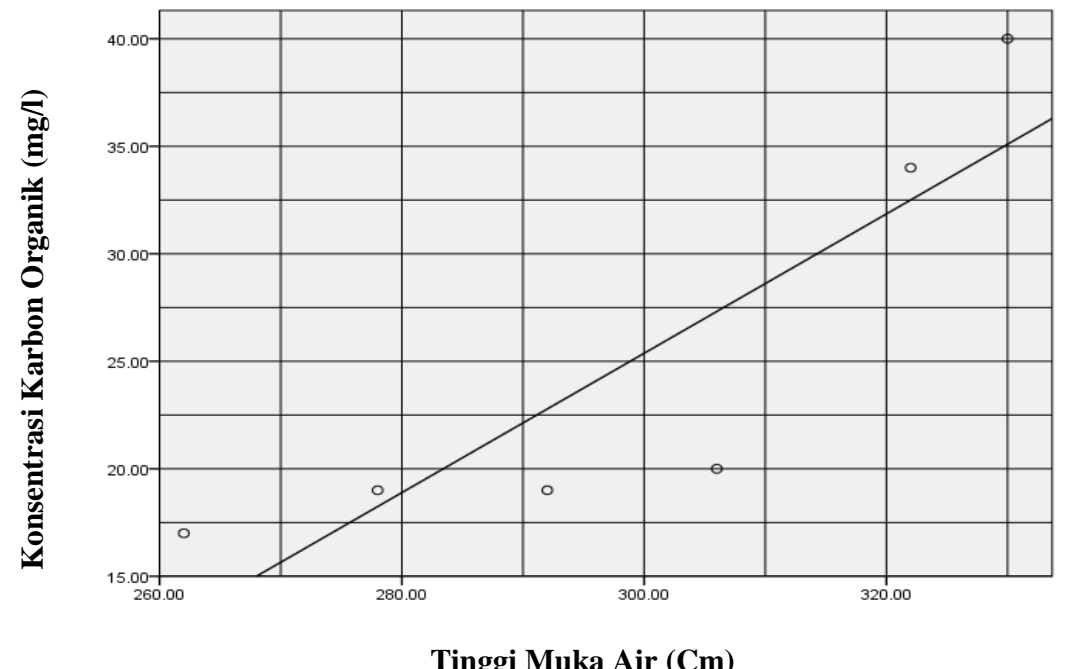

Tinggi Muka Air (Cm)

Gambar 1. Pengaruh Antara Tinggi Muka Air dengan Konsentrasi Karbon Organik di DAS Deli

Berdasarkan Gambar 1. dapat diketahui bahwa terdapat pengaruh yang cukup signifikan antara aliran permukaan dengan kehilangan karbon organik tanah yang terjadi di DAS Deli. Hal tersebut dapat dilihat dari setiap penambahan tinggi muka air yang mengindikasikan terjadinya aliran permukaan maka akan menimbulkan kenaikan konsentrasi karbon organik tanah. Berdasarkan analisis tersebut dapat disimpulkan bahwa hubungan antara aliran permukaan dengan kehilangan karbon organik tanah di DAS Deli bersifat positif. Sedangkan jika dilihat dari besaran nilai koefisien determinasi pada analisis regresi yaitu sebesar 0,764 dapat diketahui bahwa aliran permukaan mempengaruhi kehilangan karbon organik tanah sebesar $76,4 \%$. Angka tersebut merupakan angka yang cukup signifikan sehingga dapat diartikan bahwa kehilangan karbon organik tanah pada DAS Deli dipengaruhi oleh aliran permukaan sebesar $76,4 \%$ sedangkan $23,6 \%$ disebabkan oleh faktor lain.

\section{Jumlah Kehilangan Karbon Organik Tanah pada DAS Deli Per Tahun}

Jumlah kehilangan karbon organik tanah per tahun dapat dicari dengan menggunakan persamaan yang telah didapat dari hasil analisis regresi linier yaitu:

$$
Y=-71,848+0,324 x
$$

Jumlah kehilangan karbon organik tanah per tahun merupakan jumlah integral dari kehilangan karbon organik tanah bulanan di DAS Deli selama setahun. Oleh karena itu, kehilangan karbon organik tanah tahunan didapatkan dengan mengakumulasikan rerata konsentrasi karbon organik bulanan yang terjadi di DAS Deli. Adapun rerata konsentrasi karbon organik bulanan dapat diprediksi dengan menggunakan persamaan yang telah didapat dari hasil analisis regresi sebelumnya yaitu dengan mensubstitusi nilai $x$ dengan data rerata tinggi muka air di DAS bulanan yang telah didapat dari Balai Wilayah Sungai (BWS) II. Besarnya nilai $Y$ atau nilai kehilangan karbon organik tanah yang dinyatakan dengan konsentrasi karbon organik dapat diperoleh dari hasil persamaan hasil regresi. Rerata bulanan konsentrasi karbon organik di Daerah Aliran Sungai (DAS) selama setahun dapat dilihat pada tabel 3. 
Tabel 3. Rara-rata Bulanan Besaran Konsentrasi Karbon Organik di Daerah Aliran Sungai (DAS) selama Setahun

\begin{tabular}{ccc}
\hline Bulan & Rata-Rata Tinggi Muka Air & Konsentrasi Karbon Organik \\
\hline Januari & 347,10 & 40,98 \\
Februari & 282,76 & 20,13 \\
Maret & 224,84 & 1,36 \\
April & 228,00 & 2,39 \\
Mei & 260,32 & 12,86 \\
Juni & 274,33 & 17,40 \\
Juli & 279,03 & 18,92 \\
Agustus & 309,68 & 28,85 \\
September & 312,67 & 29,82 \\
Oktober & 338,06 & 38,05 \\
November & 330,67 & 35,65 \\
Desember & 345,16 & 40,35 \\
\hline & Sumber: Hasil Analisis dan Perhitungan, 2018
\end{tabular}

Kehilangan karbon organik pada Daerah Aliran Sungai selama setahun kemudian akan didapat dari kurva yang disusun dari Tabel 3 , kurva akan menunjukkan kehilangan karbon organik selama setahun. Jumlah total kehilangan karbon organik tanah selama setahun diperoleh dengan penjumlahan konsentrasi karbon organik setiap bulan. Jumlah kehilangan karbon organik setiap bulan selama setahun didapat dengan menghitung luas daerah yang berada di bawah kurva kehilangan karbon bulanan. Kurva kehilangan karbon organik pada DAS Deli ditunjukkan pada Gambar 2.

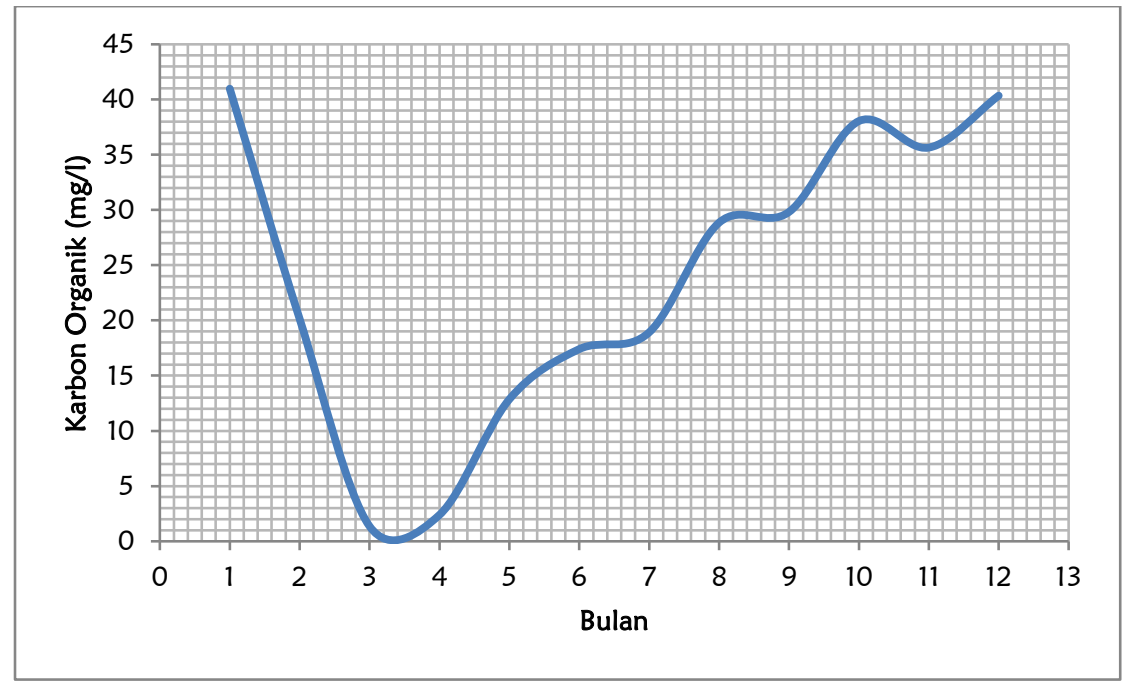

Gambar 2. Kurva Kehilangan Karbon Organik di DAS Deli

Luas dibawah kurva kehilangan karbon organik diketahui dengan menggunakan metode konsep Integral Reimenn. Kurva dibagi menjadi 2 bagian, bagian pertama yaitu daerah kurva parabola (antara titik 1-11 pada sumbu $X$ ) dan bagian kedua adalah daerah berbentuk persegi panjang dan segitiga (antara titik 11-12 pada sumbu $\mathrm{X}$ ). Luas bagian 
pertama dihitung dengan menggunakan integral tentu sedangkan luas bagian kedua dihitung dengan menggunakan rumus persegi panjang dan segitiga. Luas daerah dibawah kurva dihitung sebagai berikut:

\section{Luas 1}

Luas daerah 2 dihitung dengan menggunakan rumus integral tentu, yaitu dengan persamaan:

$$
\int_{a}^{b} F(x) d(x)
$$

dengan $f(x)$ adalah fungsi kuadrat dari parabola antara titik $(1,11)$. Pengoperasian integral tentu dapat dilakukan dengan mencari fungsi kuadrat dari parabola yang akan dihitung dengan integral. Fungsi kuadrat didapatkan dengan membuat kurva parabola menggunakan Aplikasi Microsoft Excel sehingga didapatkan fungsi $f(x)$ secara otomatis. Berikut kurva parabola luas daerah 1 pada kurva konsentrasi karbon organik:

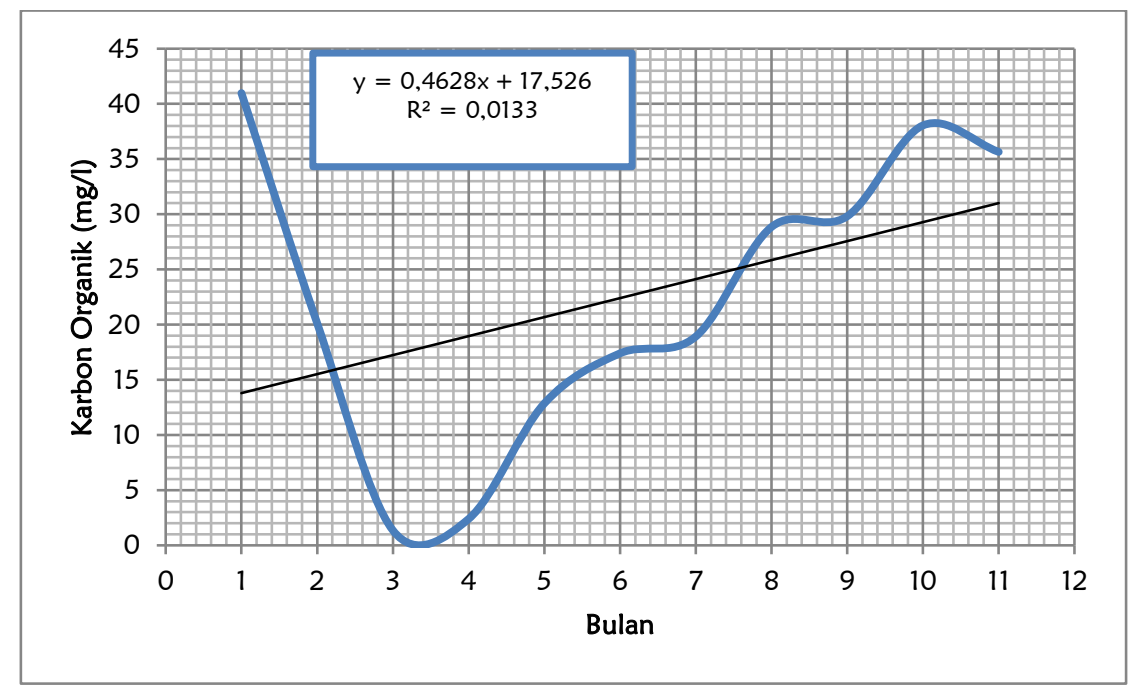

Gambar 3. Kurva Parabola (Luas 1) Konsentrasi Karbon Organik

Gambar 3 menunjukkan bahwa fungsi $f(x)$ dari parabola adalah:

$F(x)=y=0,4628 x+17,526$

Hasil integral dari fungsi $F(x)=y=0,4628 x$

$+17,526$ adalah 203,02 satuan.
Luas 2

Luas daerah 2 dihitung dengan menggunakan rumus segitiga dan segiempat, adapun daerah luas 2 pada kurva terdapat pada Gambar 4. 


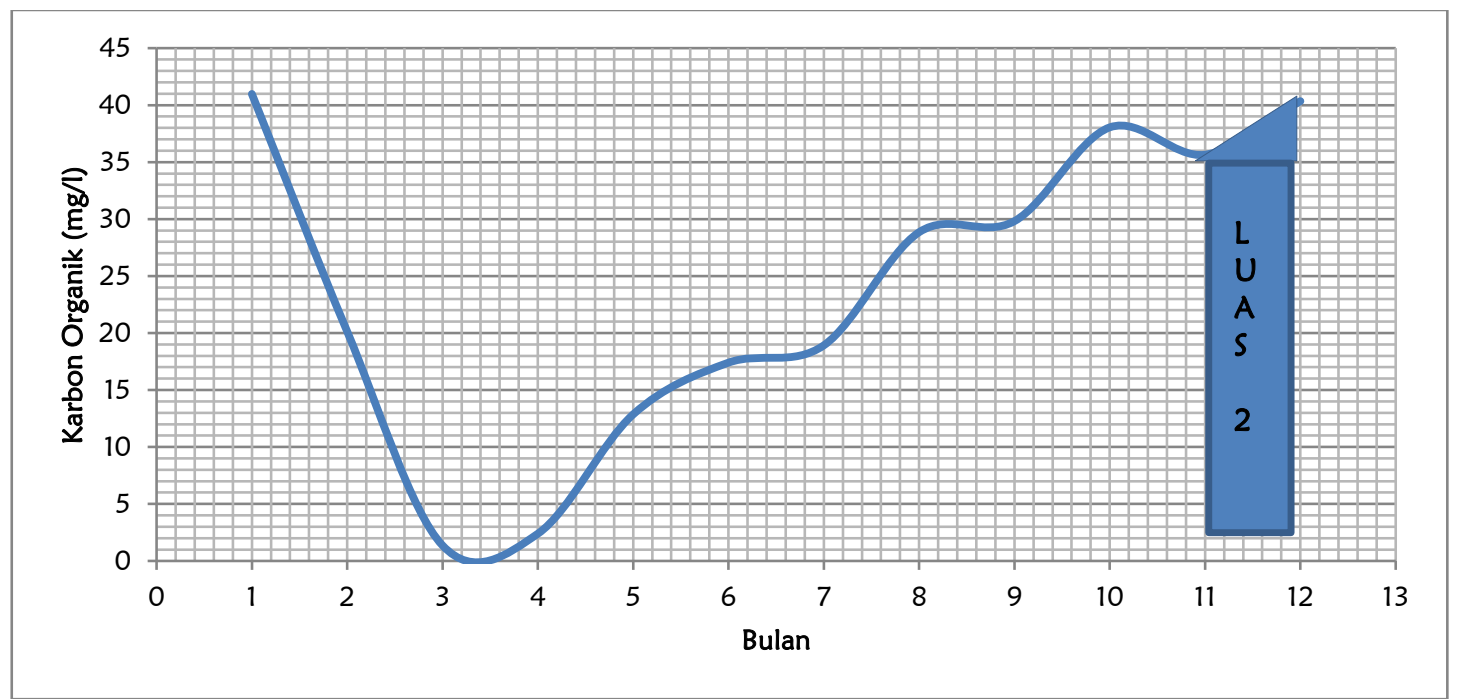

Gambar 4. Kurva Parabola Persegi Panjang dan Segitiga (Luas 2) Konsentrasi Karbon Organik

Hasil perhitungan luas 2 didapatkan luas persegi panjang adalah sebesar 35,65 satuan dan luas segitiga adalah 0,5 satuan sehingga diperoleh total luas 2 adalah sebesar 36,15 satuan. Sedangkan luas total adalah 203,02+ $35,72=239,17$ satuan

Nilai hasil perhitungan masih dinyatakan dalam satuan $\mathrm{mg} / \mathrm{l}$, yang menunjukkan nilai total kehilangan karbon organik untuk setiap liter debit air di DAS Deli. Perolehan nilai total seluruh karbon organik yang hilang selama setahun di DAS Deli didapatkan dengan mengalikan nilai perhitungan tersebut dengan besarnya volume air yang terjadi selama setahun (liter) di DAS Deli. Berdasarkan hasil perhitungan, total kehilangan karbon organik tanah di DAS Deli selama setahun adalah 286.078,47 ton/tahun. Hasil tersebut kemudian dikonversikan kedalam satuan ton dan dibagikan dengan total luas DAS Deli yaitu 47.298,01 Ha sehingga didapatkan total kehilangan karbon organik tanah pada DAS Deli selama setahun dalam satuan ton/ha/tahun. Berdasarkan hasil perhitungan didapatkan hasil yang menunjukkan bahwa total kehilangan karbon organik tanah pada DAS Deli adalah sebesar 6,04 ton/ha/tahun.

\section{Pembahasan}

Berdasarkan hasil penelitian, diketahui bahwa tinggi muka air memiliki hubungan yang signifikan dengan konsentrasi karbon organik tanah di DAS Deli yang berarti bahwa aliran permukaan berhubungan dengan proses kehilangan karbon organik tanah. Hal ini sejalan dengan penelitian Ashari (2010) yang menunjukkan adanya pengaruh erosi permukaan terhadap kehilangan karbon organik tanah.

Pengaruh dari aliran permukaan terhadap kehilangan karbon organik tanah di DAS Deli ada sebesar $76,4 \%$ sedangkan $23,6 \%$ dipengaruhi oleh faktor lainnya. DAS Deli merupakan salah satu daerah dengan tingkat erosi yang cukup tinggi. Tercatat DAS Deli mengalami erosi mencapai 407,21 ton/ha/tahun (Rahmad, 2017) yang masuk kedalam tingkat erosi berat. Erosi tersebut tentu disebabkan oleh adanya aliran permukaan yang menyebabkan pengikisan atau penghanyutan material tanah termasuk di dalamnya karbon organik tanah. Angka tersebut merupakan angka yang cukup besar sehingga menyebabkan hilangnya karbon organik tanah yang cukup besar, yaitu ketika terjadi aliran permukaan maka akan terjadi peningkatan kehilangan karbon organik tanah.

Perubahan penggunaan lahan juga merupakan salah satu faktor yang mempengaruhi kehilangan karbon organik tanah di DAS Deli. Lahan di daerah hulu yang seharusnya merupakan kawasan hutan tidak seluruhnya tertutup vegetasi. Hal tersebut dikarenakan maraknya penebangan liar yang merusak hutan sehingga fungsi hutan sebagai 
daerah tangkapan hujan dan sebagai pengendali erosi tidak berjalan sebagaimana mestinya. Tercatat $4690 \mathrm{Ha}$ lahan kritis di DAS Deli yang diakibatkan oleh penebangan liar (Tim Koordinasi Pengelolaan Sumberdaya Air, 2012). Perubahan penggunaan lahan yang terjadi menyebabkan berkurangnya tanaman sebagai penyangga dan penyerap air menyebabkan tingginya aliran permukaan yang menyebabkan terjadinya erosi. Pada suatu kasus, wilayah yang semestinya dimanfaatkan sebagai hutan apabila dikonversi menjadi bentuk penggunaan lahan yang lain akan menurunkan kapasitas input karbon organik ke dalam tanah sekaligus menyebabkan kehilangan karbon organik akibat erosi. Hal ini akan semakin buruk apabila manajemen penggunaan lahan kurang baik sehingga menimbulkan lahan kritis. Pada umumnya apabila lahan semakin terbuka dan menuju ke arah kerusakan lahan maka kandungan karbon organik tanah akan semakin menurun (Lal, 2004; Yusheng dkk, 2008 dalam Ashari,2010).

Lahan di DAS Deli banyak yang telah dikonversi. Tercatat pada tahun 2008 hingga tahun 2010 telah terjadi peningkatan perubahan penggunaan lahan ke permukiman dan pertanian lahan kering di DAS Deli. Pada tahun 2008 tercatat $12.830,026 \mathrm{Ha}(28,08 \%)$ dan meningkat menjadi 13.650,144 $\mathrm{Ha}$ (28,86\%) (Medan Bisnis, 2011).

Selain faktor perubahan penggunaan lahan dan erosi yang menyebabkan aliran permukaan, kehilangan karbon organik tanah pada DAS Deli juga disebabkan oleh karakteristik penggunaan pertanian pada sawah irigasi. Pengairan yang dilakukan sepanjang tahun dapat menyebabkan aliran permukaan sehingga menimbulkan hilangnya karbon organik tanah yang lebih besar yang dibawa oleh air (Ashari, 2010)

DAS Deli secara klimatologi merupakan daerah dengan tipe Iklim A (menurut klasifikasi Schmidt-Fergusson) dengan curah hujan tahunan yang cukup tinggi yaitu ratarata $\geq 100 \mathrm{~mm}$ per tahun. Tingginya curah hujan menyebabkan banyak aliran permukaan sehingga memungkinkan terjadinya erosi yang mengakibatkan kehilangan karbon organik tanah. Rata-rata curah hujan bulanan tertinggi pada DAS Deli pada tahun 2017 adalah sebesar 16,67 mm yaitu pada bulan Desember dan rata-rata curah hujan bulanan terendah terjadi pada bulan Maret yaitu sebesar 2,27 $\mathrm{mm}$. Berdasarkan hasil data rata-rata curah hujan bulanan (lampiran 11), Daerah Aliran Sungai Deli mengalami hujan sepanjang tahun namun intensitas hujan menaik pada bulanbulan tertentu yaitu pada bulan OktoberFebruari. Hal tersebut menyebabkan terjadinya kehilangan karbon organik sepanjang tahun di DAS Deli.

Berdasarkan hasil penelitian, Daerah Aliran Sungai Deli kehilangan karbon organik tanah 286.078,47 ton/tahun atau setara dengan 6,04 ton/ha/tahun. Berdasarkan hasil penelitian terdahulu yaitu penelitian Rahmad (2017) dengan hasil penelitian yang menunjukkan bahwa besaran erosi rata-rata Daerah Aliran Sungai (DAS) Deli selama setahun adalah 410,72 ton/ha/tahun, hal tersebut berarti dari rata-rata besaran erosi tahunan Daerah Aliran Sungai Deli yaitu 410,72 ton/ha/tahun, 6,04 ton/ha/tahun diantaranya adalah karbon organik tanah.

Jumlah kehilangan karbon organik tanah di DAS Deli yaitu 6,04 ton/ha/tahun perlu dikurangi mengingat pentingnya peran karbon organik dalam tanah. Perlu dilakukan adanya konservasi tanah baik itu secara mekanik maupun vegetatif untuk mengurangi potensi hanyutnya unsur-unsur dalam tanah di Daerah Aliran Sungai Deli. Tingginya curah hujan serta terjadinya perubahan penggunaan lahan menyebabkan proses aliran permukaan yang terjadi sepanjang tahun sehingga perlu adanya pengendalian.

\section{KESIMPULAN DAN SARAN}

Berdasarkan hasil penelitian dapat disimpulkan beberapa hal sebagai berikut:

1. Pengaruh dari aliran permukaan terhadap kehilangan karbon organik tanah di DAS Deli ada sebesar 76,4\% sedangkan 23,6\% dipengaruhi oleh faktor lainnya.

2. DAS Deli merupakan daerah seluas 47.298,01 ha dengan besar kehilangan karbon organik 6,04 ton/ha/tahun.

Mengacu pada hasil penelitian dan kesimpulan disarankan beberapa hal sebagai berikut:

1. Kehilangan karbon organik tanah yang terjadi di DAS Deli dipengaruhi oleh tingkat erosi yang tinggi, oleh sebab itu, pengendalian erosi perlu dilakukan untuk 
mengurangi kehilangan karbon organik tanah.

2. Pengendalian erosi dapat dilakukan dengan tindakan konservasi secara vegetatif, mekanik dan kimia di daerah hulu sungai untuk mengurangi tingkat erosi yang terjadi. Selain itu perlu dilakukan penghijauan lahan sebagai salah satu sumber input karbon organik.

\section{DAFTAR PUSTAKA}

Medan Bisnis, 26 Mei 2011. (Online), (http://www.medanbisnisdaily.com/epaper/2011-05-26/IV.pdf) diakses pada 25 Desember 2018

Ashari, Arif. 2010. Kehilangan Karbon Organik Oleh Aliran Permukaan di Daerah Aliran Sungai Opak Provinsi Daerah Istimewa Yogyakarta. Naskah Publikasi. Program Pascasarjana Universitas Gadjah Mada.

Ashari, Arif. 2012. Pengaruh Erosi Permukaan Terhadap Kehilangan Karbon Organik Tanah Di Sub-Daerah Aliran Sungai Opak Provinsi Daerah Istimewa Yogyakarta. Naskah Publikasi. Universitas Negeri Yogyakarta

Banuwa, Irwan. 2013. Erosi. Jakarta: PT. Fajar Interpratama Mandiri

Hutapea, Sumihar. 2012. Kajian Konservasi Daerah Aliran Sungai Deli dalam Upaya Pengelolaan Banjir di Kota Medan. Tesis. Yogyakarta: Universitas Gadjah Mada

Rahmad, Mona Adria, Ali Nurman (2017). Integrasi Model SWAT dan SIC dalam Upaya Menekan Laju Erosi DAS Deli, Sumatera Utara. Majalah Geografi Indonesia. Volume 31. Halaman 46-55

Tim Koordinasi Pengelolaan Sumberdaya Air (TKPSDA) Wilayah Sungai BelawanUlar. 2012. Pola Pengelolaan Sumber Daya Air Wilayah Sungai Belawan Ular Padang. Medan: Dinas Pekerjaan Umum

Widiyatmaka, M. Ardiansyah dan Wiwin Ambarwulan (2012). Perubahan Cadangan Karbon dalam Konteks Perubahan Penggunaan Lahan selama 2 Dekade: Studi Kasus Kabupaten Bogor, Provinsi Jawa Barat. Jurnal Globe. Volume 14. Halaman 170-177 
available at http://jurnal.unimed.ac.id/2012/index.php/tgeo

Jurnal Tunas Geografi

e-ISSN: 2622-9528 p-ISSN: 2301-606X

Vol. 08 No. $01-2019$ 